\title{
The electro-oxidation of formate ions at a polycrystalline Pt electrode in alkaline solution: an in situ FTIR study
}

\author{
P. A. Christensen,* A. Hamnett and D. Linares-Moya \\ Received 19th January 2011, Accepted 3rd May 2011 \\ DOI: $10.1039 / \mathrm{c1cp20166b}$
}

This paper reports in situ FTIR studies on the oxidation of formate at polycrystalline Pt in aqueous $\mathrm{KOH}$. Data are presented which show that hydroxyl species play a major role in the electro-oxidation of small organic molecules under alkaline conditions at polycrystalline $\mathrm{Pt}$, and that a number of possible mechanistic pathways are possible. Small changes in experimental conditions appear to be able to cause the reaction to flick between these pathways; for example, the presence of oxygen has a marked effect upon the observed electrochemistry. In contrast to acid solution, our postulated model includes the formation of intermediates bonded through $\mathrm{O}$ atoms, rather than $\mathrm{C}$, as being an important option in alkaline solution. Finally, the $\mathrm{pH}$ distribution across the reflective electrode in external reflectance IR is modelled and significant variations in $\mathrm{pH}$ across the electrode surface in FTIR cells predicted and confirmed experimentally.

\section{Introduction}

The key advantage of alkaline fuel cells (AFC's, hydrogen as fuel, oxygen as oxidant) is that the oxygen reduction reaction is more facile in alkaline media ${ }^{1-4}$ resulting in the highest cell voltage at a given current density if $\mathrm{Pt}$ is employed at the anode and cathode, and allowing access to a wider range of cheaper cathode catalyst materials such as perovskites and $\mathrm{Ag},{ }^{1,5}$ as well as lower Pt loadings. The Alkaline Fuel Cell was the first fuel cell to be developed commercially, and is the best performing of all fuel cells ${ }^{1,3,4,6,7}$ capable of better than $300 \mathrm{~mW} \mathrm{~cm}{ }^{-2}$ at $75{ }^{\circ} \mathrm{C}$ and using air as the oxidant, and $80 \mathrm{~mW} \mathrm{~cm}{ }^{-2}$ at $40{ }^{\circ} \mathrm{C}$ under the same conditions; ${ }^{1}$ even at room temperature, it performs well. ${ }^{8}$ The performance of the AFC is such that, in contrast to $\mathrm{H}_{2} / \mathrm{O}_{2}$ Proton Electrolyte Membrane Fuel Cell (PEMFC) data which are typically reported at $90{ }^{\circ} \mathrm{C}$ in the literature, AFC data are usually given for $40{ }^{\circ} \mathrm{C}{ }^{8}$

Methanol oxidation under alkaline conditions is also more facile in alkaline electrolyte than in acid, up to an order of magnitude greater, ${ }^{2,9,10}$ and $\mathrm{Pt}$ anodes are not poisoned by chemisorbed fragments as is the case in acid electrolyte; thus a liquid electrolyte alkaline DMFC stack gave a maximum output of $1.5 \mathrm{~W} \mathrm{~cm}^{-2}$ at $0.25 \mathrm{~V}, 48{ }^{\circ} \mathrm{C}$ and using pressurised oxygen. ${ }^{9}$ Alkaline fuel cell technology remained focussed on the use of aqueous $\mathrm{KOH}$ as the electrolyte, and hence problems associated with the carbonation of the $\mathrm{KOH}$ and precipitation of $\mathrm{K}_{2} \mathrm{CO}_{3}$ essentially restricted the AFC to extra-terrestrial applications, excluding the use of air as

School of Chemical Engineering and Advanced Materials,

Bedson Building, Newcastle University, Newcastle upon Tyne, NE1 7RU, England, UK oxidant and small organic molecules or reformate as fuel. ${ }^{2,10-12}$ The advent of Polymer Electrolyte Membranes (PEM's) and especially Nafion reduced considerably the engineering complexity associated with liquid electrolytes, and the failure to develop a stable and conductive anionic equivalent to PEM's (Alkaline Anion Exchange Membranes, AAEM's) consigned research on alkaline fuel cells to something of a backwater. $^{7}$

Recent research on the development of novel AAEM's by, for example, the Surrey group ${ }^{13,14}$ and Coates and co-workers ${ }^{15,16}$ has re-ignited interest in AFC's, and in direct alcohol AFC's in particular. AAEM's employ immobilised, cationic head groups such as tetra-alkylammonium $\left(-\mathrm{NR}_{3}{ }^{+}\right)$and hence there are no metal cations to cause carbonate precipitation. Use of an AAEM, as in the case of PEM-based fuel cells, will reduce engineering complexity and allows, in principle, the use of reformate or small organic molecules as fuel. Furthermore, in contrast to the PEM-based Direct Methanol Fuel Cell, water transport in a direct alcohol AFC would be from the cathode to anode, opposing the cross-over of alcohol to the cathode which leads to a mixed potential and concomitant loss of performance. ${ }^{10}$ Concerns over the carbonation of the AAEM resulting in a significant voltage drop across the membrane, due to the need for accommodating $\mathrm{OH}^{-}$ions generated at the cathode with the requirement to hold the $\mathrm{pH}$ at the anode sufficiently low for $\mathrm{CO}_{2}$ to be lost, ${ }^{17}$ appear not to be borne out by experimental evidence. ${ }^{18,19}$ Hence, the search for novel catalysts for the anode of direct alcohol AFC's remains a valid aim in electro-catalysis.

We recently reported ${ }^{20}$ an in situ FTIR study of the oxidation of methanol at a polycrystalline $\mathrm{Pt}$ electrode in aqueous $\mathrm{KOH}$ 
as part of an ongoing research programme. We observed a band near $1317 \mathrm{~cm}^{-1}$ which we were able to assign unambiguously to adsorbed formate; ${ }^{20-26}$ the formate is an important intermediate in methanol oxidation under the conditions employed (in our work, adsorbed $\mathrm{CO}$ appeared to be a spectator species, rather than an intermediate) and is adsorbed through both oxygen atoms rather than through the carbon atom, both significant observations. Formate adsorbed through both oxygen atoms has also been observed during the oxidation of methanol at Pt in acid solution, but whether it is an intermediate in methanol oxidation in acid remains controversial ${ }^{24-26}$ not least because the coverage of formate does not correlate with methanol concentration ${ }^{26}$ and it is now generally accepted that, in acid electrolyte, methanol chemisorbs through the carbon atom via sequential stripping of hydrogen atoms, with $\mathrm{Pt}_{3} \mathrm{COH}$ or $\mathrm{PtCO}$ as important intermediates, depending upon methanol concentration. ${ }^{27}$ In alkaline solution this would not appear to be the dominant pathway with alternative routes involving $\mathrm{Pt}-\mathrm{O}$ bonds available. Furthermore, the activation energies of these alternative pathways seem to be sufficiently similar that small changes can cause the methanol oxidation reaction to 'flick' across to a different pathway. This was shown by $\mathrm{us}^{20}$ in experiments in $\mathrm{O}_{2}$-saturated methanolic $\mathrm{KOH}$ where no evidence for linearly adsorbed $\mathrm{CO}\left(\mathrm{CO}_{\mathrm{L}}\right)$ was seen at all, and all the methanol consumption appeared to be via the adsorbed formate intermediate. In addition, when the concentration of solution formate builts up sufficiently, re-adsorption of formate to $\mathrm{CO}_{\mathrm{L}}$ was observed, reinforcing the postulated non-linear and dynamic nature of methanol oxidation under alkaline conditions.

In order to explore the above concepts further, we have investigated the oxidation of formate at polycrystalline $\mathrm{Pt}$ in both nitrogen- and oxygen-saturated aqueous $\mathrm{KOH}$, and the results so obtained are presented below.

\section{Experimental}

The electrolyte solutions were prepared using Millipore water $(18.2 \mathrm{M} \Omega \mathrm{cm})$ and analytical grade sulfuric acid (Aldrich). Aqueous 0.1 M KOH (Aldrich SigmaUltra > 85\% KOH basis) was employed as supporting electrolyte. In order to ameliorate $\mathrm{pH}$ effects in the thin layer ${ }^{20}$ it would have been advantageous to employ higher concentrations of $\mathrm{KOH}$, but such concentrations would lead to an unacceptably high rate of etching of the prismatic window. Sodium formate (Aldrich A.C.S. Reagent $>99 \%$ ) was used as received. Nitrogen gas from a cryogenic boil-off was employed to de-aerate the solutions and to maintain an air-free atmosphere over the electrolyte during the measurements. Oxygen was obtained from BOC (UN1072 99.6\% $\mathrm{O}_{2}$ ). All potentials are given vs. the $\mathrm{Hg} / \mathrm{HgO}$ (Mercury/ Mercury Oxide) electrode in aqueous $0.1 \mathrm{M} \mathrm{NaOH}$. The polycrystalline $\mathrm{Pt}$ electrode was 'top hat' shaped with an area of $0.64 \mathrm{~cm}^{2}$ polished and exposed to the electrolyte. ${ }^{28,29}$ The electrode was polished with $0.015 \mu \mathrm{m}$ alumina (BDH), washed thoroughly with Millipore water and then immersed in Millipore water in an ultrasonic bath for several minutes prior to transfer into the spectroelectrochemical cell. The cleanliness of the electrolyte and cell was assessed by cyclic voltammetry.

The in situ FTIR experiments were performed using a Varian FTS-7000 spectrometer equipped with a Globar infrared source and a narrow-band MCT detector. The potentiostat was an Autolab PGSTAT. ${ }^{12}$ The spectroelectrochemical cell was home-built and fitted with a hemispherical $\mathrm{CaF}_{2}$ window ${ }^{28-30}$ (Medway optics Ltd). The cell was mounted vertically on the lid of the sample compartment of the spectrometer and was designed to allow electrolyte exchange under potential control. The cell was jacketed to allow careful control of the temperature of the electrolyte in the body of the cell. Details of the PTFE electrode holder, cell and mounting/temperature control system may be found elsewhere. ${ }^{30-33}$

The in situ FTIR experiments were carried out as follows: after collecting cyclic voltammograms in the absence of methanol, the potential was held at $-0.85 \mathrm{~V}$ and sodium formate added to a final concentration of $0.1 \mathrm{M}$, after which the electrode was pressed against the $\mathrm{CaF}_{2}$ cell window and the spectrometer allowed to purge free of $\mathrm{CO}_{2}$ and water vapour (ca. 30-60 min). The reference spectrum $\left(\mathrm{S}_{R}, 100\right.$ co-added and averaged scans at $8 \mathrm{~cm}^{-1}$ resolution, $c a$. $35 \mathrm{~s}$ per scan set) was collected and a second spectrum taken at the same potential (to check for electrode movement etc), after which spectra $\left(\mathrm{S}_{S}\right)$ were collected at $-0.8 \mathrm{~V}$ and then every $100 \mathrm{mV}$ up to $0.4 \mathrm{~V} v s$. MMO. The spectra below are presented as:

$$
\text { Absorbance }=-\log _{10}\left(\frac{\mathrm{S}_{S}}{\mathrm{~S}_{R}}\right)
$$

This data manipulation results in difference spectra in which peaks pointing up, to + (Absorbance), arise from the gain of absorbing species in $\mathrm{S}_{S}$ with respect to $\mathrm{S}_{R}$, and peaks pointing down, to -(Absorbance), to the loss of absorbing species.

The optical path-length was estimated from the $1640 \mathrm{~cm}^{-1}$ $\mathrm{H}-\mathrm{O}-\mathrm{H}$ scissor band in the single beam reference spectrum, using an extinction coefficient ${ }^{34}$ of $21 \mathrm{~mol}^{-1} \mathrm{dm}^{3} \mathrm{~cm}^{-1}$ and a water concentration of $55.6 \mathrm{M}$. The angle of incidence of the IR beam (assuming $0^{\circ}$ beam divergence) on the $\mathrm{CaF}_{2}(n=1.41, k=0)^{35}$ / electrolyte interface was $46^{\circ}$ (normal incidence at the $\mathrm{CaF}_{2} /$ air interface), giving an angle of incidence at the Pt electrode (assuming $n=1.33$ and approximating $k$ to 0 for water) of $51^{\circ}$. Even allowing for $\pm 6^{\circ}$ beam spread, the incidence on the inner side of the $\mathrm{CaF}_{2}$ /electrolyte interface is well below the critical angle, hence precluding any enhancement effects due to total internal reflectance. ${ }^{35}$ The path-lengths in the experiments discussed below were both $c a .2 .0 \mu \mathrm{m}$, giving thin layer thicknesses of $c a$. $0.6 \mu \mathrm{m}$.

\section{Results}

\section{Voltammetry}

The cyclic voltammetric response of polycrystalline $\mathrm{Pt}$ (pc-Pt) in $\mathrm{N}_{2}$ and $\mathrm{O}_{2}$-saturated $0.1 \mathrm{M} \mathrm{KOH}$ was discussed in the previous paper; ${ }^{20}$ briefly, when compared to the voltammetry in acid solution there is an additional, small wave having an onset near $-0.5 \mathrm{~V}$ vs. MMO which may be attributed to the reversible formation of $\mathrm{OH}_{\mathrm{ads}}{ }^{21}$ This peak is enhanced in $\mathrm{O}_{2}$-saturated $\mathrm{KOH}$.

\section{In situ FTIR experiments}

The changes in current observed during the FTIR experiments in $\mathrm{N}_{2}$ and $\mathrm{O}_{2}$ are shown in Fig. 1 . In both $\mathrm{N}_{2}$ and $\mathrm{O}_{2}$ saturated 


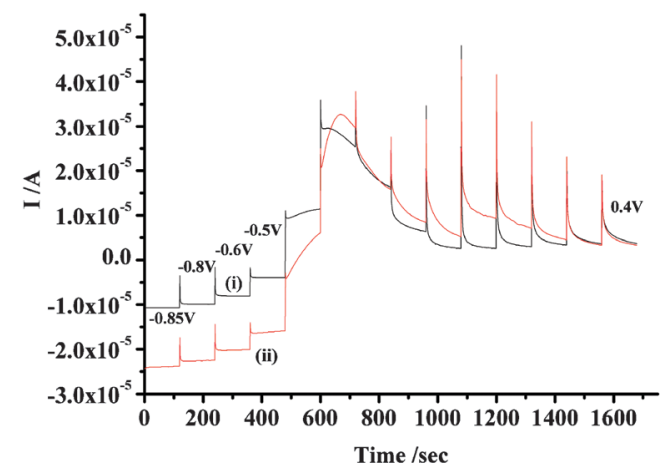

Fig. 1 The variation in the current observed during the in situ FTIR experiments on the oxidation of $0.1 \mathrm{M} \mathrm{NaOOCH}$ in (i) $\mathrm{N}_{2}$ and (ii) $\mathrm{O}_{2}$-saturated $0.1 \mathrm{M} \mathrm{KOH}$.

solutions there is cathodic current passed until $-0.6 \mathrm{~V}$, with large increases in anodic current at $-0.5 \mathrm{~V}$ to $-0.3 \mathrm{~V}$; up to $-0.6 \mathrm{~V}$, the cathodic component of the nett current, due to oxygen reduction, is significantly greater in $\mathrm{O}_{2}$ saturated solution, as may be expected. ${ }^{36}$ The large increase in anodic current at potentials $>-0.5 \mathrm{~V}$ may indicate the involvement of $\mathrm{OH}_{\text {ads }}$ in the electrochemical process. ${ }^{26,37,38}$

Fig. 2 shows the spectra collected at $-0.8 \mathrm{~V}$ to $-0.6 \mathrm{~V}$, i.e. potentials where a nett cathodic current flows, in $\mathrm{N}_{2}$ saturated $0.1 \mathrm{M} \mathrm{KOH}+0.1 \mathrm{M} \mathrm{NaOOCH}$. As may be seen from the figure, both linearly adsorbed $\mathrm{CO}\left(\mathrm{CO}_{\mathrm{L}}, 2005 \mathrm{~cm}^{-1}\right)$ and bridge-bonded $\mathrm{CO}\left(\mathrm{CO}_{\mathrm{B}}, 1805 \mathrm{~cm}^{-1}\right)^{20,39-41}$ are formed from the chemisorption of formate; the fact that neither of these features are bipolar indicates that there is no, or very little, adsorbed $\mathrm{CO}$ present in the reference spectrum collected at $-0.85 \mathrm{~V}$, and hence the $\mathrm{CO}_{\mathrm{L}}$ and $\mathrm{CO}_{\mathrm{B}}$ species result from chemisorption of formate at potentials $>-0.85 \mathrm{~V}$. This observation is in agreement with the fact that, during methanol oxidation under the same conditions, ${ }^{20}$ high concentrations of formate resulted in re-absorption to form $\mathrm{CO}_{\mathrm{L}}$. Solution carbonate is formed at $-0.6 \mathrm{~V}$, band near ${ }^{20,41,42} 1400 \mathrm{~cm}^{-1}$, presumably due to the participation of $\mathrm{OH}_{\mathrm{ads}}$; however, there is no clear decline in the intensity of the $\mathrm{CO}_{\mathrm{L}}$ or $\mathrm{CO}_{\mathrm{B}}$ features

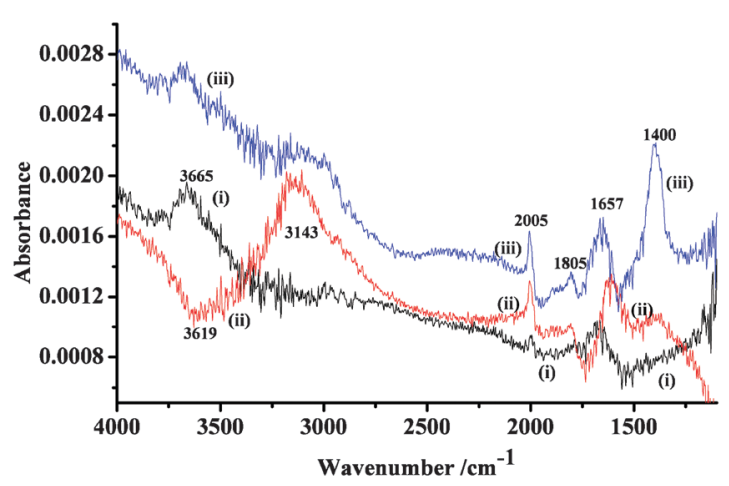

Fig. 2 In-situ FTIR spectra (100 co-added and averaged scans, $8 \mathrm{~cm}^{-1}$ resolution) of a polycrystalline $\mathrm{Pt}$ electrode $\left(0.64 \mathrm{~cm}^{2}\right)$ immersed in $\mathrm{N}_{2}$-saturated $0.1 \mathrm{M} \mathrm{NaOOCH}+0.1 \mathrm{M} \mathrm{KOH}$ collected at (i) $-0.8 \mathrm{~V}$, (ii) $-0.7 \mathrm{~V}$ and (iii) $-0.6 \mathrm{~V}$. The reference spectrum was taken at $-0.85 \mathrm{~V}$ vs. MMO and a second, absorbance spectrum collected at the same potential to ensure that the system was stable with respect to, for example, electrode movement. at $-0.6 \mathrm{~V}$. Features near $1657 \mathrm{~cm}^{-1}$ and associated with the appearance of $\mathrm{HCO}_{3}{ }^{-}$or $\mathrm{CO}_{3}{ }^{2-}$ are often attributed to uncompensated water in the thin layer or to the instability of the latter. ${ }^{21,40-43}$ It is surprising that carbonate is formed at a potential lower than the onset of $\mathrm{OH}_{\text {ads }}$ formation: however, in acid solution, formic acid oxidation is believed to proceed by a 'dual path' mechanism. ${ }^{25}$ Direct oxidation takes place via one or more weakly adsorbed intermediates and proceeds to $\mathrm{CO}_{2}$ without the formation of adsorbed $\mathrm{CO}$ and indirect oxidation proceeds via adsorbed CO. Formic acid oxidation by the direct pathway does not require an external oxygen source such as $\mathrm{OH}_{\mathrm{ads}}$ and hence formic acid oxidation can take place at more negative potentials than required for $\mathrm{H}_{2} \mathrm{O}$ dissociation on $\mathrm{Pt}^{25}$

In addition to the bands due to adsorbed $\mathrm{CO}$ and $\mathrm{CO}_{3}{ }^{2-}$ in Fig. 2, there is clearly a major change in the nature of the water layer adjacent to the electrode, as may be seen from the behaviour of the water bands, particularly at $-0.7 \mathrm{~V}$ where the water features are seen as two bipolar bands, centred near $3300 \mathrm{~cm}^{-1}$ and $1660 \mathrm{~cm}^{-1}$, showing that both the $\mathrm{O}-\mathrm{H}$ stretch and $\mathrm{H}-\mathrm{O}-\mathrm{H}$ deformation of the interfacial water are shifting to lower frequency as the potential is increased from $-0.85 \mathrm{~V}$ to $-0.7 \mathrm{~V}$, suggesting a concomitant increase in hydrogen bonding, perhaps due to association with a charged ion ${ }^{44-46}$ such as $\mathrm{OH}^{-}$or $\mathrm{CO}_{3}{ }^{2-}$.

Fig. 3 shows analogous spectra to those in Fig. 2 from the experiment conducted in $\mathrm{O}_{2}$-saturated $\mathrm{KOH}$. A consistent observation is that there are very clear differences between the spectra in $\mathrm{O}_{2}$-saturated electrolyte as compared to $\mathrm{N}_{2}$-saturated: in $\mathrm{O}_{2}$, in contrast to the case in $\mathrm{N}_{2}$-saturated solution, there is a clear, steady gain of bands associated with interfacial water, with the frequencies of both the $\mathrm{O}-\mathrm{H}$ stretch and $\mathrm{H}-\mathrm{O}-\mathrm{H}$ deformation jumping to lower values at $-0.7 \mathrm{~V}$ with the appearance of $\mathrm{CO}_{\mathrm{L}}$; i.e. 3584 to $3370 \mathrm{~cm}^{-1}$ and 1669 to $1644 \mathrm{~cm}^{-1}$, respectively, suggesting an increase in hydrogen bonding. In contrast, in acid solution, the formation of a hydrophobic $\mathrm{CO}_{\text {ads }}$ layer is often associated with water bands shifting to higher frequency, due to a decrease in hydrogen bonding associated with the water molecules adjacent to, or buried within, the $\mathrm{CO}_{\text {ads }}$ domains. ${ }^{23}$ Fig. 1 shows that marked $\mathrm{O}_{2}$ reduction is taking place in the potential region depicted in Fig. 3; in a previous paper ${ }^{47}$ we reported that $\mathrm{O}_{2}$ reduction at $\mathrm{Au}$ in aqueous $\mathrm{KOH}$ was accompanied by the gain of water features near 3300 and $1640 \mathrm{~cm}^{-1}$.

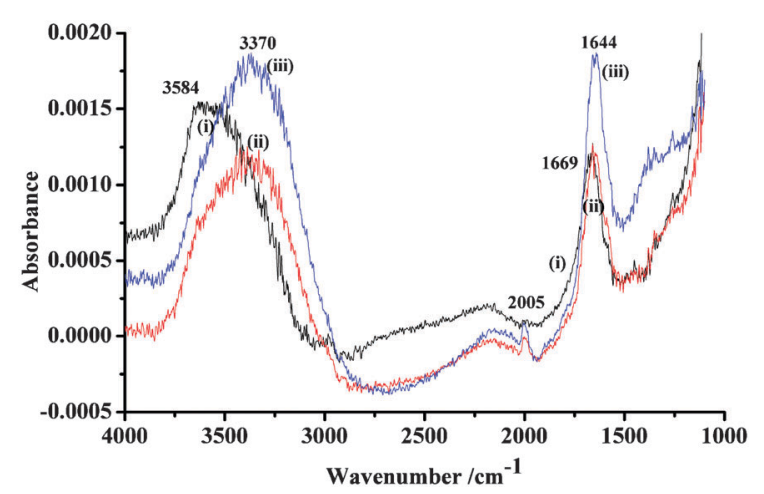

Fig. 3 In-situ FTIR spectra of the polycrystalline Pt electrode $\left(0.64 \mathrm{~cm}^{2}\right)$ immersed in $\mathrm{O}_{2}$-saturated $0.1 \mathrm{M} \mathrm{NaOOCH}+0.1 \mathrm{M}$ $\mathrm{KOH}$ collected at (i) $-0.8 \mathrm{~V}$, (ii) $-0.7 \mathrm{~V}$ and (iii) $-0.6 \mathrm{~V}$. The reference spectrum was taken at $-0.85 \mathrm{~V}$ vs. MMO. 
A very significant difference between Fig. 2 and 3 is the absence of $\mathrm{CO}_{3}{ }^{2-}$ in the latter; this is not observed until $-0.5 \mathrm{~V}$ in $\mathrm{O}_{2}$-saturated solution (see Fig. 5) and suggests that the reduction of oxygen at the electrode is inhibiting the formation of the reactive intermediate on the path to $\mathrm{CO}_{3}{ }^{2-}$, but not the chemisorption of formate to $\mathrm{CO}_{\mathrm{L}}$, which is formed in both $\mathrm{N}_{2}$ and $\mathrm{O}_{2}$ saturated solutions, albeit the absorbance of the feature in the latter experiment is halved from $3.0 \times 10^{-4}$ in $\mathrm{N}_{2}$ to $1.5 \times 10^{-4}$ at $-0.6 \mathrm{~V}$. This suggests that, as was observed by us during the oxidation of methanol under similar conditions, ${ }^{21}$ adsorbed $\mathrm{CO}$ is a spectator rather than a participant in the oxidation of formate to $\mathrm{CO}_{3}{ }^{2-}$.

Umeda and co-workers ${ }^{36}$ have reported that methanol oxidation at electro-catalysts produced by co-sputtering $\mathrm{Pt}$ and $\mathrm{C}$ is enhanced in the presence of $\mathrm{O}_{2}$ for certain compositions. The authors interpreted their data in terms of a model in which the reduction of $\mathrm{O}_{2}$ at $\mathrm{Pt}$ generates adsorbed $\mathrm{OH}$ which inhibits the oxygen reduction reaction, but enhances methanol oxidation through the removal of adsorbed $\mathrm{CO}^{48}$

$$
\mathrm{Pt}-\mathrm{CO}+\mathrm{Pt}-\mathrm{OH} \rightarrow 2 \mathrm{Pt}+\mathrm{CO}_{2}+\mathrm{H}^{+}+\mathrm{e}^{-}
$$

Fig. 4 shows spectra collected from $-0.6 \mathrm{~V}$ to $-0.20 \mathrm{~V}$ in the $\mathrm{N}_{2}$ experiment depicted in Fig. 2. As may be seen from the figure, at $-0.5 \mathrm{~V}$ and $-0.4 \mathrm{~V}$, a broad loss feature between $3100 \mathrm{~cm}^{-1}$ and $1700 \mathrm{~cm}^{-1}$ appears with minima near $2750 \mathrm{~cm}^{-1}$ and $1950 \mathrm{~cm}^{-1}$ and grows at higher potentials, i.e. tracking the $\mathrm{OH}_{\text {ads }}$ feature in the voltammograms. This broad IR band was attributed to the loss of solution $\mathrm{OH}^{-}$in our previous paper ${ }^{20}$ and tentatively assigned to the formation of $\mathrm{OH}_{\text {ads }}$ from solution $\mathrm{OH}^{-}$. Confirmation of the assignment of the broad loss band comes from the work of Śmiechowski and Stangret ${ }^{49}$ who deconvoluted the IR spectrum of ' $\mathrm{MOH}$ affected water' $(\mathrm{M}=\mathrm{Li}, \mathrm{Na}$ and $\mathrm{K})$ and assigned bands at 2845 and $2020 \mathrm{~cm}^{-1}$ so obtained to the continuum absorbance (ref. 51 and 52, p. D163) which is largely absent in bulk, neutral water. The $\mathrm{O}-\mathrm{H}$ stretches and $\mathrm{H}-\mathrm{O}-\mathrm{H}$ deformations are present in both forms of water, and hence consumption of $\mathrm{OH}^{-}$in the thin layer would be expected to result in the loss of these continuum absorptions, compare Fig. 3(a) and (b) in ref. 49.

It is clear from Fig. 4 that $\mathrm{CO}_{\mathrm{L}}$ is present throughout the potential range of the figure, and that the production of $\mathrm{CO}_{3}{ }^{2-}$

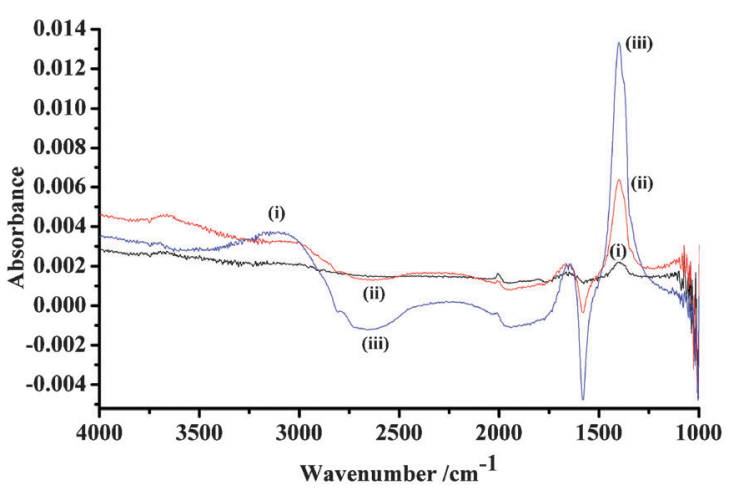

Fig. 4 In situ FTIR spectra of the polycrystalline Pt electrode $\left(0.64 \mathrm{~cm}^{2}\right)$ immersed in $\mathrm{N}_{2}$-saturated $0.1 \mathrm{M} \mathrm{NaOOCH}+0.1 \mathrm{M}$ $\mathrm{KOH}$ collected at (i) $-0.6 \mathrm{~V}$, (ii) $-0.5 \mathrm{~V}$ and (iii) $-0.4 \mathrm{~V}$. The reference spectrum was taken at $-0.85 \mathrm{~V}$ vs. MMO.

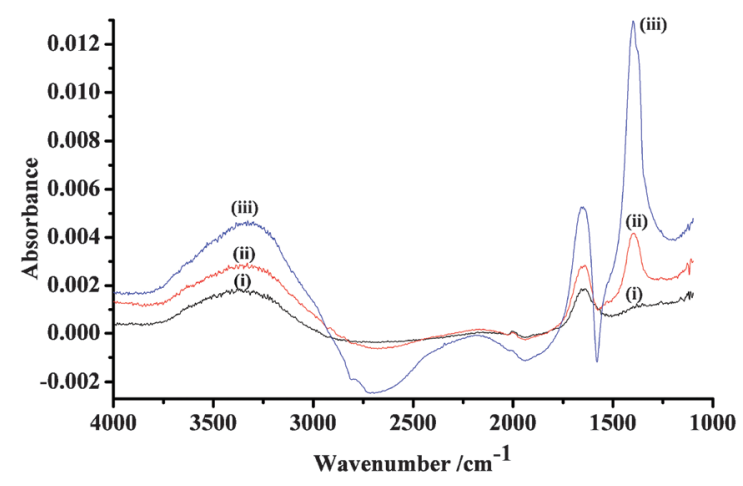

Fig. 5 In situ FTIR spectra of the polycrystalline Pt electrode immersed in $\mathrm{O}_{2}$-saturated $0.1 \mathrm{M} \mathrm{NaOOCH}+0.1 \mathrm{M} \mathrm{KOH}$ collected at (i) $-0.6 \mathrm{~V}$, (ii) $-0.5 \mathrm{~V}$ and (iii) $-0.4 \mathrm{~V}$. The reference spectrum was taken at $-0.85 \mathrm{~V}$ vs. MMO.

increases significantly at $-0.5 \mathrm{~V}$ and $-0.4 \mathrm{~V}$, with the concomitant loss of the solution formate band near $1581 \mathrm{~cm}^{-1} .^{20}$ The analogous experiment in $\mathrm{O}_{2}$ saturated $\mathrm{KOH}$ to that depicted in Fig. 4 is shown in Fig. 5. Again, $\mathrm{CO}_{\mathrm{L}}$ is present at all potentials and $\mathrm{CO}_{3}{ }^{2-}$ is produced at potentials $\geq-0.5 \mathrm{~V}$; however, in contrast to the experiment in $\mathrm{N}_{2}$, the formate loss feature is only observed at $-0.4 \mathrm{~V}$ and, as was mentioned above, the appearance of the carbonate is $100 \mathrm{mV}$ higher than in $\mathrm{N}_{2}$ saturated $\mathrm{KOH}$. Furthermore, in Fig. 5, the water gain features are more intense than in Fig. 4.

The differences in the IR response between $\mathrm{N}_{2}$ and $\mathrm{O}_{2}$ saturated $\mathrm{KOH}$ are even more marked over the potential range $-0.4 \mathrm{~V}$ to $-0.1 \mathrm{~V}$, see Fig. 6 and 7 . A comparison of the spectra collected at $-0.4 \mathrm{~V}$ and $-0.1 \mathrm{~V}$ in the experiments depicted in Fig. 6 and 7 is presented in Fig. 8(a) and (b), respectively, and plots of the $\mathrm{CO}_{2}$ absorbance observed in the $\mathrm{N}_{2}$ and $\mathrm{O}_{2}$ experiments between $-0.85 \mathrm{~V}$ and $+0.4 \mathrm{~V}$ are shown in Fig. 8(c).

The differences in behaviour between $\mathrm{N}_{2}$ and $\mathrm{O}_{2}$ saturated $\mathrm{KOH}$ are clear in the figures. The feature at $2340 \mathrm{~cm}^{-1}$ may be attributed to solution $\mathrm{CO}_{2}$ the onset potential of which is $-0.3 \mathrm{~V}$ in both $\mathrm{O}_{2}$ and $\mathrm{N}_{2}$ saturated electrolyte (see Fig. 8(c)), and which suggests that the $\mathrm{pH}$ in the thin layer is comparable to or less than $\mathrm{p} K_{\mathrm{a}, 1}$ of carbonic acid $\left(6.37 ; \mathrm{p} K_{\mathrm{a}, 2}=10.25\right)^{51}$ at the potentials in

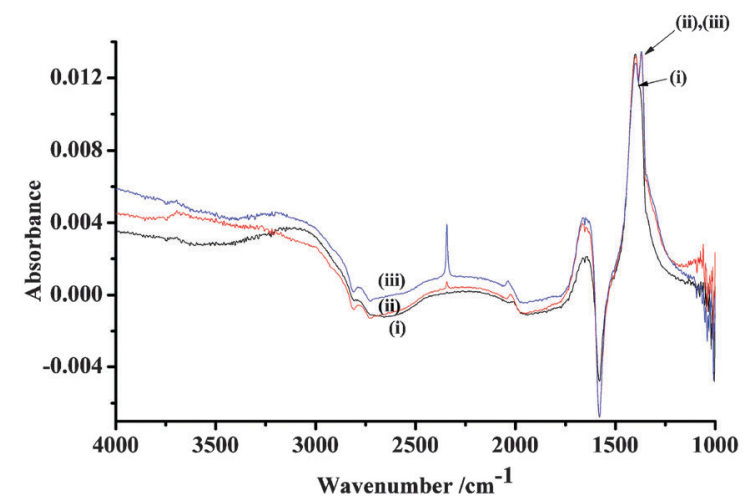

Fig. 6 In situ FTIR spectra of the polycrystalline Pt electrode immersed in $\mathrm{N}_{2}$-saturated $0.1 \mathrm{M} \mathrm{NaOOCH}+0.1 \mathrm{M} \mathrm{KOH}$ collected at $-0.4 \mathrm{~V}$ to $-0.2 \mathrm{~V}$. The reference spectrum was taken at $-0.85 \mathrm{~V} v s$. MMO. 


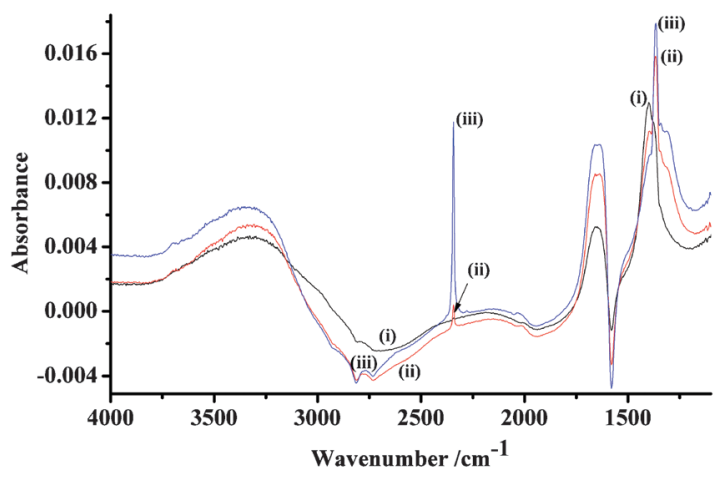

Fig. 7 In situ FTIR spectra of the polycrystalline Pt electrode immersed in $\mathrm{O}_{2}$-saturated $0.1 \mathrm{M} \mathrm{NaOOCH}+0.1 \mathrm{M} \mathrm{KOH}$ collected at (i) $-0.4 \mathrm{~V}$ to (iii) $-0.2 \mathrm{~V}$. The reference spectrum was taken at $-0.85 \mathrm{~V}$ vs. MMO.
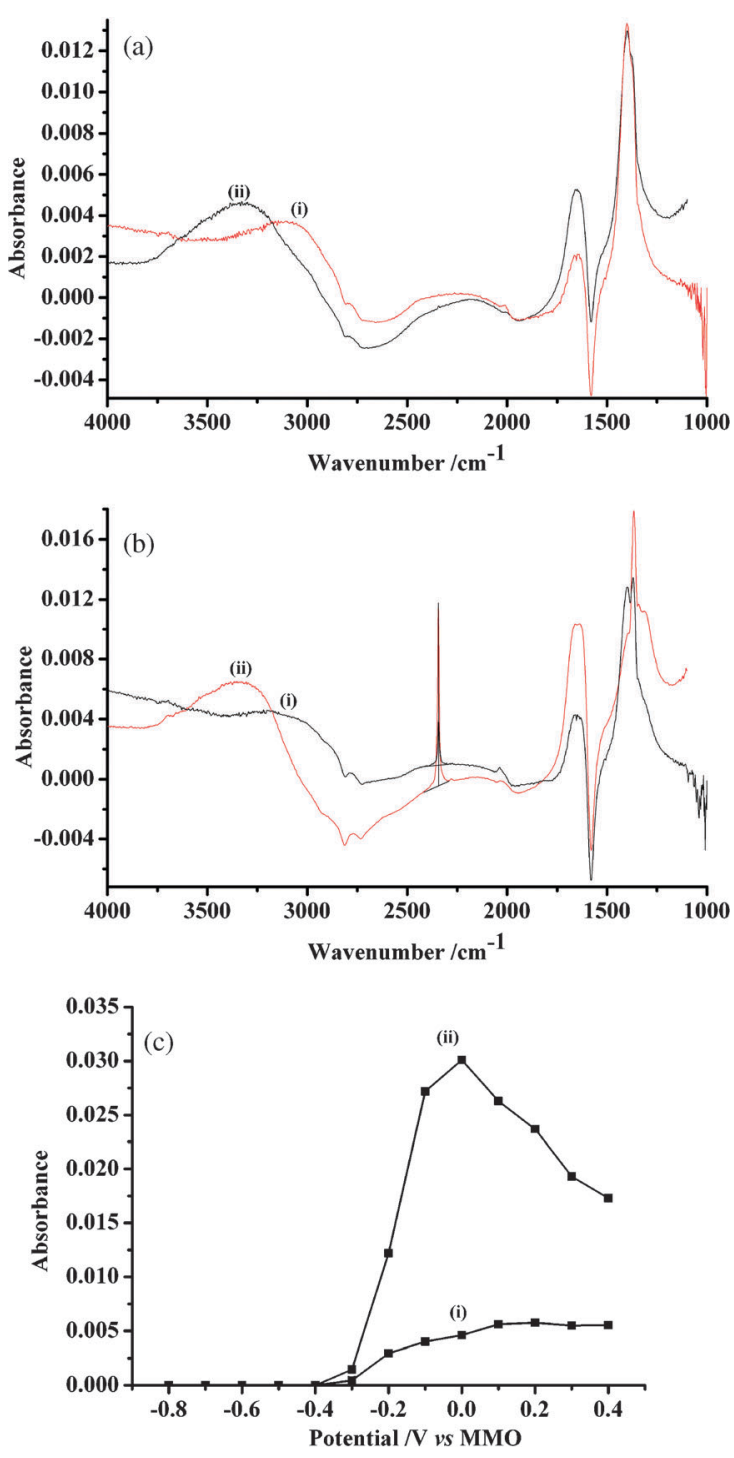

Fig. 8 The spectra collected at (a) $-0.4 \mathrm{~V}$ and (b) $-0.1 \mathrm{~V}$ in Fig. 6 and 7. (c) Plots of $\mathrm{CO}_{2}$ absorbance at $2340 \mathrm{~cm}^{-1}$ from the experiments depicted in Fig. 4 and 5. (i) $\mathrm{N}_{2}$ - and (ii) $\mathrm{O}_{2}$-saturated $\mathrm{KOH}$. the figure. From Fig. 8(c) it can be seen that the $\mathrm{CO}_{2}$ produced in the two experiments is very significantly different, with $c a$. $5 x$ more generated in the $\mathrm{O}_{2}$ experiment, supporting our postulate that the mechanism is very finely balanced; the decrease in the $\mathrm{CO}_{2}$ absorbance at potentials $>0 \mathrm{~V}$ is due to the $\mathrm{CO}_{2}$ forming bubbles and pushing the electrolyte out of the thin layer. ${ }^{20}$

Fig. 8(a) shows the spectra collected at $-0.4 \mathrm{~V}$ in the $\mathrm{N}_{2}$ and $\mathrm{O}_{2}$-saturated electrolyte; apart from the changes in the interfacial water structure, there is very little difference between the two spectra, and the absorptions of the $\mathrm{CO}_{3}{ }^{2-}$ bands are comparable. Closer inspection of both the $\mathrm{CO}_{3}{ }^{2-}$ features in Fig. 8(a) suggests a shoulder to the $\mathrm{CO}_{3}{ }^{2-}$ feature on the low wave-number side, and this is seen more clearly in Fig. 8(b), and Fig. 6 and 7, where a sharper feature grows in at $1366 \mathrm{~cm}^{-1}$ in both experiments. However, whilst the feature grows on the side of the carbonate peak in $\mathrm{N}_{2}$-saturated solution, it dominates the spectra collected in $\mathrm{O}_{2}$-saturated $\mathrm{KOH}$, increasing to a maximum intensity at $-0.1 \mathrm{~V}$, with a concomitant decrease in the $1400 \mathrm{~cm}^{-1} \mathrm{CO}_{3}{ }^{2-}$ band. The data in Fig. 6, 7, 8(a) and (b) suggest that the $1366 \mathrm{~cm}^{-1}$ band grows with the carbonate band up to $-0.4 \mathrm{~V}$, before the division in behaviour takes place. The broad band in the $\mathrm{H}-\mathrm{O}-\mathrm{H}$ deformation region near $1650 \mathrm{~cm}^{-1}$ seems to grow with the $1366 \mathrm{~cm}^{-1}$ feature. The former is clearly not entirely due to water as there is no matching increase in the $\mathrm{O}-\mathrm{H}$ stretching region, compare Fig. 8(a) and (b), and the 1366 and $1650 \mathrm{~cm}^{-1}$ bands may be attributed to the symmetric and asymmetric stretching bands of $\mathrm{HCO}_{3}{ }^{-}$in solution. ${ }^{42}$ However, this would require $\mathrm{CO}_{3}{ }^{2-}, \mathrm{HCO}_{3}{ }^{-}$and $\mathrm{CO}_{2}$ to be present at the same time in the spectra in Fig. 6-8, which clearly is not a viable option if the solution is homogeneous.

In fact the situation with regard to the very thin-layer cell used in electrochemical reflectance IR is such that under a wide variety of conditions a substantial $\mathrm{pH}$ gradient can form across the radial dimension of the electrode surface. The reason for this is that lateral diffusion of $\mathrm{OH}^{-}$is extremely slow compared to diffusion between the electrode and window, and this can be modelled with the equations for cylindrical diffusion, as described by Crank. ${ }^{54}$ The details of the model are given in the Appendix, and a representative result is given for the oxidation of an organic molecule in which $\mathrm{OH}^{-}$is consumed at the rate of four ions for every organic molecule oxidised, and we assume for simplicity that the initial concentrations of formate and hydroxyl ions are the same as are their diffusion coefficients. In practice, qualitatively similar results are obtained for a very wide variety of input conditions, and these will be the subject of separate contribution in due course. The essential point is that the formation of a $\mathrm{pH}$ gradient is almost inevitable in the types of thin-layer cells used in specular reflection FTIR, and must be borne in mind in interpreting the data.

The possibility that the $1366 \mathrm{~cm}^{-1}$ band is due to $\mathrm{HCO}_{3}{ }^{-}$in ionically isolated regions of electrolyte is supported by its persistence. The band is present as a gain feature in both $\mathrm{N}_{2}$ and $\mathrm{O}_{2}$ spectra up to $+0.4 \mathrm{~V}$ normalised to the reference taken at $-0.85 \mathrm{~V}$, see Fig. 9(a) and (b). For example, in $\mathrm{O}_{2}$ saturated $\mathrm{KOH}$, see Fig. 9(b), the $\mathrm{CO}_{2}$ gas evolution is such that the solution is pushed out of the thin layer, as shown by the large loss features near $3300 \mathrm{~cm}^{-1}$ and $1650 \mathrm{~cm}^{-1}$ due to 'MOH affected' bulk water, ${ }^{20,49}$ and the solution formate bands near 1581,1382 

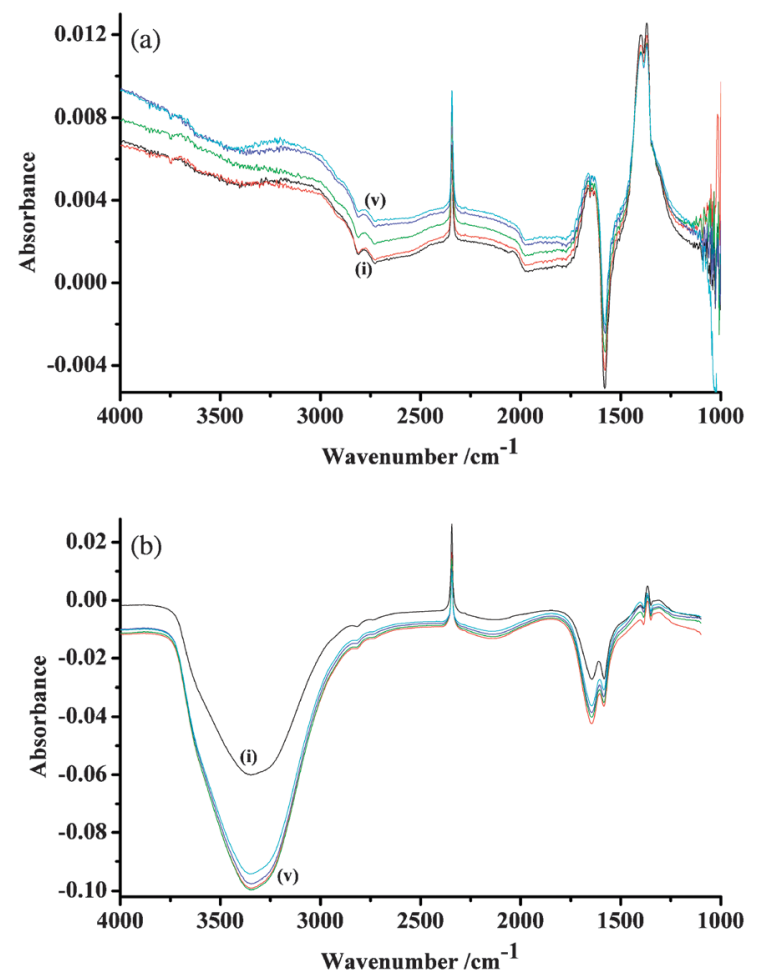

Fig. 9 In situ FTIR spectra of the polycrystalline Pt electrode immersed in (a) $\mathrm{N}_{2}$ and (b) $\mathrm{O}_{2}$-saturated $0.1 \mathrm{M} \mathrm{NaOOCH}+0.1 \mathrm{M}$ $\mathrm{KOH}$ collected at (i) $0 \mathrm{~V}$, (ii) $0.1 \mathrm{~V}$, (iii) $0.2 \mathrm{~V}$, (iv) $0.3 \mathrm{~V}$ and (v) $0.4 \mathrm{~V}$. The reference spectra were taken at $-0.85 \mathrm{~V}$ vs. MMO.

and $1351 \mathrm{~cm}^{-1}$, yet the $1366 \mathrm{~cm}^{-1}$ band is relatively unchanged over the potential range from $0 \mathrm{~V}$ to $0.4 \mathrm{~V}$. The $\mathrm{CO}_{2}$ evolution in Fig. 9(a) is insufficient for bubbles to form, see Fig. 8(c). Fig. 9(a) also clearly shows the persistence of the $\mathrm{CO}_{\mathrm{L}}$ feature, which is retained throughout the $-0.8 \mathrm{~V}$ to $-0.2 \mathrm{~V}$ potential range, albeit at a lower intensity in $\mathrm{O}_{2}$ saturated $\mathrm{KOH}$ than $\mathrm{N}_{2}$ saturated. Loss features due to 'bulk' water, coupled with the gain of $\mathrm{CO}_{2}$, have been observed before and unambiguously attributed to $\mathrm{CO}_{2}$ bubble formation and the concomitant ejection of electrolyte from the thin layer (see, for example, ref. 20). However, there may well be a contribution from the increased coverage of the surface by O-containing species, leading to blockage of active sites, and hence decreasing $\mathrm{CO}_{2}$ formation.

\section{Discussion}

The results of the methanol oxidation experiments described previously ${ }^{20}$ clearly demonstrate that the main active intermediate in methanol oxidation in alkaline solution is not carbon-bonded but rather bonded through oxygen. This is quite different from the situation in acidic electrolytes, where carbonbonded intermediates appear to constitute the major mechanistic pathways, and it raises the question of why, in alkaline solution, there is such a difference. One important distinction in alkaline solutions is the presence of significantly higher concentrations of $\mathrm{OH}_{\mathrm{ads}}$ which will tend to polarise the Pt atoms at the surface through the adsorbed $\sigma$-acceptor hydroxy-species leading to stabilisation of bonding to surface-adsorbed $\sigma$-donors such as formate and related species. It is unclear whether this is a dominant effect, however; one important aspect of the oxidation of even simple organic species is the apparently very small energy differences between different reaction pathways, and small differences in the nature of the electrode surface may be able to tip reactions into very different routes. This effect is exacerbated by the non-linearity of the kinetic equations; this non-linearity can lead to very complex and unpredictable behaviour that has been recognised for many years (ref. 53, p. 86 ), giving rise to phenomena such as oscillations in the reaction rate. It is important to recognise that this sensitivity to reaction conditions means that experiments in which the morphology of the $\mathrm{Pt}$ is substantially altered, or in which the potential protocol departs too far from that normally found in fuel cells, may well lead to different pathways dominating.

It is also clear from the results above that $\mathrm{Pt}-\mathrm{C}$ bonds do indeed form in alkaline solution, and both $\mathrm{CO}_{\mathrm{L}}$ and $\mathrm{CO}_{\mathrm{B}}$ can be identified in the spectra. However, the intensity of these bands suggests that they are not participants in the electrochemical processes on the surface, but rather simply play a spectator role. The coverage of $\mathrm{CO}_{\mathrm{ads}}$ is also rather insensitive to the formate concentration. At $-0.6 \mathrm{~V}$, for example, in $1 \mathrm{M}$ formate, the IR absorbance is $4 \times 10^{-4}$ and in $0.1 \mathrm{M}$ formate, the absorbance is very similar: $3.3 \times 10^{-4}$ and this rather suggests that there is a proportion of the surface, perhaps a facet of a particular face such as (111) that does adsorb $\mathrm{CO}$ but on other facets $\mathrm{OH}_{\mathrm{ads}}$ successfully competes, destabilising the $\mathrm{CO}_{\mathrm{ads}}$ and stabilising O-bonded adsorbates. Support for this notion comes from the observation that in the presence of $\mathrm{O}_{2}$, very much less $\mathrm{CO}_{\mathrm{ads}}$ is seen compared with $\mathrm{N}_{2}$-saturated solution.

This is an interesting observation, since it suggests that the main role of the oxygen is to increase the coverage of $\mathrm{OH}_{\mathrm{ads}}$, which has the two consequences of reducing surfaceblocking by $\mathrm{CO}_{\mathrm{ads}}$ and enhancing the stability of active O-bonded intermediates. The total charge passed in the presence of $\mathrm{O}_{2}$ is significantly larger than that passed in the presence of $\mathrm{N}_{2}$, by a factor of about $20 \%$ accounting for the difference in overall product quantities seen in the two experiments. Given the relative quantities of formate oxidised and $\mathrm{O}_{2}$ present, this must be a catalytic effect rather than involving the direct participation of $\mathrm{O}_{2}$ itself, and it would appear that our model of the $\mathrm{OH}_{\text {ads }}$ as an important promoter in this system, and particularly its ability to prevent surface blocking by $\mathrm{CO}_{\mathrm{ads}}$ is supported by the experimental evidence above.

Finally, our results shed light on the assignment of the IR features due to $\mathrm{OH}^{-}$(aq.); the broad loss features normally observed in external reflectance IR spectra in alkaline solution and associated with the consumption of $\mathrm{OH}^{-}$ions may be attributed to the continuum absorptions of aqueous $\mathrm{OH}^{-}$.

\section{Conclusions}

The FTIR data for the oxidation of formate in alkaline electrolyte demonstrate that adsorbed hydroxyl species can have a major effect on steering the reaction mechanism as well as participating directly in the oxidation of intermediates in the formate oxidation itself. Part of the surface is covered with $\mathrm{OH}_{\mathrm{ads}}$ even in the presence of $\mathrm{N}_{2}$, and it would appear that coverage of part of the surface with adsorbed $\mathrm{CO}$ is inhibited 
by the $\mathrm{OH}_{\text {ads }}$. In the presence of $\mathrm{O}_{2}$, additional $\mathrm{OH}_{\text {ads }}$ forms as a result of $\mathrm{O}_{2}$ reduction at lower potentials, so that as the potential is ramped up, even less $\mathrm{CO}_{\mathrm{ads}}$ forms than in the presence of $\mathrm{N}_{2}$, giving a more active surface. The presence of $\mathrm{OH}_{\text {ads }}$ has two effects: it prevents part of the surface being blocked by adsorbed spectator species such as $\mathrm{CO}_{\text {ads }}$ and it facilitates adsorption of active O-bonded species. At higher potentials, once $\mathrm{OH}_{\text {ads }}$ has formed, it can be replenished by oxidation of water, and the surface retains a high coverage of $\mathrm{OH}_{\mathrm{ads}}$ giving it a high activity.

\section{Appendix 1-lateral diffusion in the FTIR cell}

The basic equation for cylindrical diffusion of a single species is:

$$
\frac{\partial c}{\partial t}=D\left(\frac{\partial^{2} c}{\partial r^{2}}+\frac{1}{r} \frac{\partial c}{\partial r}\right)
$$

which can be discretised as a dimensionless set of equations following the substitutions $C=c / C^{*}$, where $C^{*}$ is the reference concentration of the species (taken here as the concentration of the initial reactant in the bulk of the cell), $R=r / a$ where $a$ is the radius of the cylinder, and $T=D t / a^{2}$; given that $a$ may be macroscopic this may lead to very long overall times being needed in the simulation. We have:

$$
\frac{\partial C}{\partial T}=\left(\frac{\partial^{2} C}{\partial R^{2}}+\frac{1}{R} \frac{\partial C}{\partial R}\right)
$$

and if we arrange lattice points at a distance $H$ apart, such that $R=i H$ then for $i \neq 0$

$$
\begin{aligned}
\left(\frac{\partial^{2} C}{\partial R^{2}}+\frac{1}{R} \frac{\partial C}{\partial R}\right) \equiv & \frac{1}{2 i H^{2}}\{(2 i+1) C(i+1)-4 i C(i) \\
& +(2 i-1) C(i-1)\}
\end{aligned}
$$

where $C(i)$ is the normalised concentration at the $i^{\text {th }}$ point. For $i=0$, using the Bessel function expansion at small $r$ :

$$
\frac{1}{R} \frac{\partial}{\partial R}\left(R \frac{\partial C}{\partial R}\right)=\frac{4}{H^{2}}(C(1)-C(0))
$$

For the Crank-Nicholson implicit approach, we have, for $i \neq 0$ :

$$
\begin{aligned}
\frac{C^{\prime}(i)-C(i)}{\delta T}= & \frac{1}{4 i H^{2}}\{(2 i+1) C(i+1) \\
& -4 i C(i)+(2 i-1) C(i-1)\} \\
& \times \frac{1}{4 i H^{2}}\left\{(2 i+1) C^{\prime}(i+1)-4 i C^{\prime}(i)\right. \\
& \left.+(2 i-1) C^{\prime}(i-1)\right\}
\end{aligned}
$$

where $C^{\prime}(i)$ is the concentration at position $i$ at time $t+\delta T$, and $\lambda=\frac{\delta T}{H^{2}}$ whence

$$
\begin{aligned}
& \lambda(2 i-1) C^{\prime}(i-1)-4 i(\lambda+1) C^{\prime}(i)+\lambda(2 i+1) C^{\prime}(i+1) \\
& \quad=-\lambda(2 i-1) C(i-1)+4 i(\lambda-1) C(i)-\lambda(2 i+1) C(i+1)
\end{aligned}
$$

and for $i=0$ :

$$
\begin{aligned}
\frac{C^{\prime}(0)-C(0)}{\delta T}= & \frac{2}{H^{2}}\left(C^{\prime}(1)-C^{\prime}(0)\right)+\frac{2}{H^{2}}(C(1) \\
& -C(0))
\end{aligned}
$$

whence:

$-(1+2 \lambda) C^{\prime}(0)+2 \lambda C^{\prime}(1)=-(1-2 \lambda) C(0)-2 \lambda C(1)$

whilst for $i=N$ we have, for fixed $C(N+1)$ :

$$
\begin{aligned}
\lambda(2 N-1) C^{\prime}(N-1)-4 N(1+\lambda) C^{\prime}(N) \\
=-(2 N-1) \lambda C(N-1)+4 N(\lambda-1) C(N) \\
\quad-2(2 N+1) \lambda C(N+1)
\end{aligned}
$$

The method of solution is to use a powerful sparse matrix inverter from the Harwell suite, MA28AD, to solve a set of matrix equations derived from a sparse matrix. The matrix is set up by defining the row and column numbers for each entry, and then calling MA28AD. Note that the linear equations to be solved have a dimension $(N+1)$ and the matrix has the form:

and:

$$
\mathbf{M}=\left(\begin{array}{ccccccc}
-1+2 \lambda & 2 \lambda & 0 & 0 & 0 & \ldots & 0 \\
\lambda & -8(\lambda+1) & 3 \lambda & 0 & 0 & \ldots & 0 \\
0 & 3 \lambda & -12(\lambda+1) & 5 \lambda & 0 & \ldots & 0 \\
\vdots & & & & & & \\
0 & 0 & 0 & \ldots & 0 & (2 N-1) \lambda & -4 N(\lambda+1)
\end{array}\right)
$$

$$
\mathbf{M} \times\left(\begin{array}{c}
C^{\prime}(0) \\
C^{\prime}(1) \\
\vdots \\
C^{\prime}(N)
\end{array}\right)=\left(\begin{array}{c}
-(1-2 \lambda) C(0)-2 \lambda C(1) \\
-\lambda C(i-1)+4(\lambda-1) C(i)-\lambda 3 C(i+1) \\
\vdots \\
-(2 N-1) \lambda C(N-1)+4 N(\lambda-1) C(N)-2(2 N+1) \lambda C(N+1)
\end{array}\right)
$$


In the geometry found in specular infra-red cells, the cylindrical electrode is pressed against an infra-red-transparent window, leaving a narrow electrolyte gap of about 1 micron width. The electrolyte contains an electroactive material which is assumed to be consumed at a rate proportional to $k_{\mathrm{f}} c$ and if the cell gap is $h$ then the pure diffusion equation transforms to:

$$
\frac{\partial c}{\partial t}=D\left(\frac{\partial^{2} c}{\partial r^{2}}+\frac{1}{r} \frac{\partial c}{\partial r}\right)-k_{\mathrm{f}} c / h
$$

Using the same normalisations as before, we find:

$$
\frac{\partial C}{\partial T}=\left(\frac{\partial^{2} C}{\partial R^{2}}+\frac{1}{R} \frac{\partial C}{\partial R}\right)-\frac{k_{\mathrm{f}} a^{2}}{\mathrm{Dh}} C
$$

We can form the Crank-Nicholson equations essentially in the same way as above, and save for the end points we have:

$$
\begin{aligned}
& \lambda(2 i-1) C^{\prime}(i-1)-\left[4 i(\lambda+1)+\frac{2 k_{\mathrm{f}} a^{2}}{\mathrm{Dh}} \delta T\right] C^{\prime}(i) \\
& +\lambda(2 i+1) C^{\prime}(i+1)=-\lambda(2 i-1) C(i-1) \\
& +\left[4 i(\lambda-1)+\frac{2 k_{f} a^{2}}{\mathrm{Dh}} \delta T\right] C(i)-\lambda(2 i+1) C(i+1)
\end{aligned}
$$

with similar equations for the end points $i=0$ and $i=N$. Similar, if more complex equations, can be written down in the event that we have two electroactive species, or we have a single electroactive species being converted into a surface adsorbed species. Whilst the equations become more complex, and the dimension of the matrix $M$ steadily increases, there is nothing fundamentally novel introduced, save in the event that higher-order chemical or electrochemical reactions take place. If the rate of reaction is proportional to the concentration of two diffusing species, then the rate constant $k_{\mathrm{f}}$ now contains a product term: $k_{\mathrm{f}} c_{\mathrm{A}} c_{\mathrm{B}}$. Thus, if we focus on the oxidation of small organic molecules in alkaline solution, the rate of the electrochemical reaction will depend on $\left[\mathrm{OH}^{-}\right]$. This introduces a non-linearity into the equations, and this can be accommodated by using an implicit method as described by Britz (ref. 55, p. 136): here the product $k c_{\mathrm{A}} c_{\mathrm{B}}$ is replaced by $\frac{1}{2} k\left(c_{\mathrm{A}}^{\prime} c_{\mathrm{B}}+c_{\mathrm{A}} c_{\mathrm{B}}^{\prime}\right)$

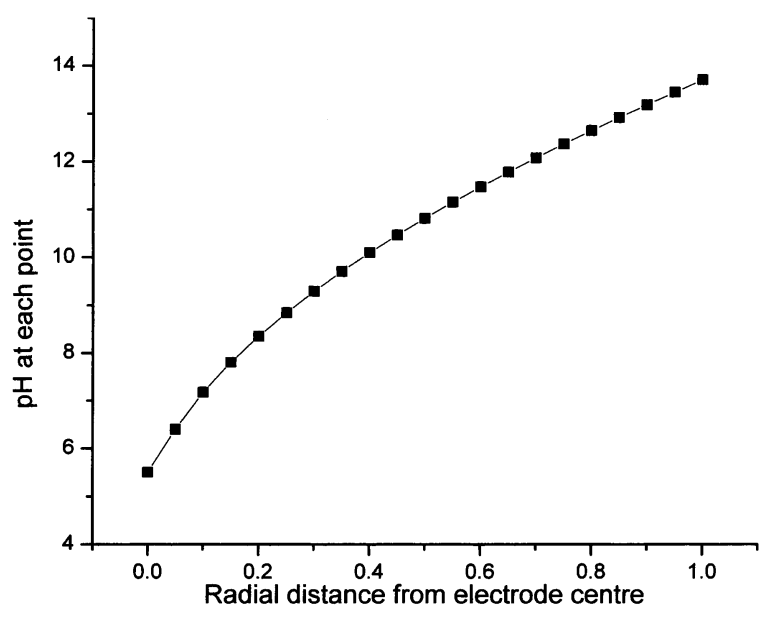

Fig. $10 \mathrm{pH}$ variation across the electrode surface for a model calculation using the approach in Appendix 1.
The method above has been programmed in Fortran 77 and some typical results for a model system in which an organic molecule is oxidised in the presence of $\mathrm{OH}^{-}$to a surfacebound species are shown in Fig. 10. The $\mathrm{pH}$ distribution across the electrode is shown as close to linear after some $10^{3} \mathrm{~s}$, varying from 5 up to 13 in the $0.1 \mathrm{M}$ solution investigated. The important point about the figure is that the limitation on the diffusion rate of $\mathrm{OH}^{-}$leads to a range of $\mathrm{pH}$ values being exhibited simultaneously across the electrode, and thus such a range will be seen in the resultant spectrum. It is, therefore, perfectly possible for the outer part of the electrode to be close to $\mathrm{pH} 13$ but the inner part, near the centre, to be at a much lower $\mathrm{pH}$; all products over the range of $\mathrm{pH}$ values will be seen. In the case of oxidation of formate, it is, therefore, possible to see simultaneously $\mathrm{CO}_{3}{ }^{2-}, \mathrm{HCO}_{3}{ }^{-}$and $\mathrm{CO}_{2}$, an important point to bear in mind when assignments are being made.

\section{Acknowledgements}

DLM would like to thank Universidad del Zulia for sponsorship.

\section{References}

1 G. F. McLean, T. Niet, S. Prince-Richard and N. Djilali, Int. J. Hydrogen Energy, 2002, 27, 507.

2 J. S. Spendelow and A. Wieckowski, Phys. Chem. Chem. Phys., 2007, 9, 2654

3 E. H. Yu, U. Krewer and K. Scott, Energies (Basel, Switz.), 2010, 3, 1499.

4 E. Antolini and E. R. Gonzalez, J. Phys. Chem., 2010, 195, 3431.

5 R. S. Jayashree, D. Egas, J. S. Spendelow, D. Natarajan, L. J. Markoski and P. J. A. Kenis, Electrochem. Solid-State Lett., 2006, 9, A252.

6 J. Larminie and A. Dicks, Fuel Cell Systems Explained, Wiley, Chichester, UK, 2nd edn, 2004.

7 W. Vielstich, A. Lamm and H. A. Gasteiger, Handbook of Fuel Cells, Wiley, Chichester, UK, 2003, vol. 1-6.

8 K. Kordesch, in ref. 7, vol. 1 p. 267.

9 J. Prabhuram and R. Manoharan, J. Power Sources, 1998, 74, 54.

10 J. R. Varcoe and R. C. T. Slade, Fuel Cells, 2005, 5, 187.

11 E. J. Guzlow, J. Power Sources, 1996, 61, 99.

12 M. Cifrain and K. V. Kordesch, J. Power Sources, 2004, 127, 234.

13 J. R. Varcoe, R. C. T. Slade, E. L. H. Yee, S. D. Poynton, D. J. Driscoll and D. C. Apperley, Chem. Mater., 2007, 19, 2686.

14 S. D. Poynton, J. P. Kizewski, R. C. T. Slade and J. R. Varcoe, Solid State Ionics, 2010, 181, 219.

15 N. J. Robertson, H. A. Kostalik IV, T. J. Clark, P. F. Mutolo, H. D. Abruña and G. W. Coates, J. Am. Chem. Soc., 2010, 132, 3400 .

16 H. A. Kostalik IV, T. J. Clark, N. J. Robertson, P. F. Mutolo, J. M. Longo, H. D. Abruña and G. W. Coates, Macromolecules, 2010, 43, 7147.

17 Y. Wang, L. Li, L. Hu, L. Zhuang, J. Lu and B. Xu, Electrochem. Commun., 2003, 5, 662.

18 C. Bianchini, V. Bambagione, J. Filippi, F. Vizza, P. Bert and A. Tampucci, Electrochem. Commun., 2009, 11, 1077.

19 P. A. Christensen, A. Hamnett and D. Linares-Moya, Phys. Chem. Chem. Phys., 2011, 13, 5206.

20 P. A. Christensen and D. J. Linares-Moya, J. Phys. Chem. C, 2010, 114, 1094.

21 Q. S. Chen, S. G. Sun, Z. Y. Zhou, Y. X. Chen and S. B. Deng, Phys. Chem. Chem. Phys., 2008, 10, 3645.

22 M. Endo, T. Matsumoto, J. Kubota, K. Domen and C. Hirose, J. Phys. Chem. B, 2000, 104, 4916.

23 A. Miki and M. Osawa, Chem. Commun., 2002, 1500. 
24 Y.-X. Chen, M. Heinen, Z. Jusys and R. J. Behm, Langmuir, 2006, 22, 10399.

25 Y.-X. Chen, Y. Shen, M. Heinen, Z. Jusys, M. Osawa and R. J. Behm, J. Phys. Chem. B, 2006, 110, 9534.

26 K. Kunimatsu, H. Hanawa, H. Uchida and M. Watanabe, J. Electroanal. Chem., 2009, 632, 109.

27 A. Hamnett, in Interfacial Electrochemistry: Theory Experiment and Applications, ed. A. Wieckowski, Marcel Dekker, New York, 1999, p. 843.

28 W. F. Lin, P. A. Christensen, A. Hamnett, M. S. Zei and G. Ertl, J. Phys. Chem. B, 2000, 104, 6642.

29 W. F. Lin, P. A. Christensen and A. Hamnett, J. Phys. Chem. B, 2000, 104, 12002.

30 W. F. Lin, P. A. Christensen, J. M. Jin and A. Hamnett, in In-situ Spectroscopic Studies of Adsorption at the Electrode and Electrocatalysis, ed. S. G. Sun, P. A. Christensen and A. Wieckowski, Elsevier, Amsterdam, 2007, p. 99.

31 J. M. Jin, W. F. Lin and P. A. Christensen, J. Electroanal. Chem., 2004, 563, 71.

32 P. A. Christensen, J. M. Jin, W. F. Lin and A. Hamnett, J. Phys. Chem. B, 2004, 108, 3391.

33 J. M. Jin, W. F. Lin and P. A. Christensen, Phys. Chem. Chem. Phys., 2008, 10, 3774.

34 J. G. Bayly, V. B. Kartha and W. H. Stevens, Infrared Phys., 1963 , 3, 211.

35 P. W. Faguy and W. R. Fawcett, Appl. Spectrosc., 1990, 44, 1309.

36 M. Umeda, K. Nagai, M. Shibamine and M. Inoue, Phys. Chem. Chem. Phys., 2010, 12, 7041.

37 Y. X. Chen, A. Miki, S. Ye, H. Sakai and M. Osawa, J. Am. Chem. Soc., 2003, 125, 3680.

38 G. Garcia and M. T. M. Koper, Phys. Chem. Chem. Phys., 2009, 11, 11437.
39 E. Morallón, A. Rodes, J. L. Vázquez and J. M. Pérez, J. Electroanal. Chem., 1995, 391, 148.

40 Z.-Y. Zhou, N. Tian, Y.-J. Chen, S.-P. Chen and S.-G. Sun, J. Electroanal. Chem., 2004, 573, 111.

41 G. García, P. Rodríguez, V. Rosca and M. T. M. Koper, Langmuir, 2009, 25, 13661.

42 K. Arihara, F. Kitamura, T. Ohsaka and K. Tokuda, J. Electroanal. Chem., 2001, 510, 128.

43 T. Iwasita, A. Rodes and E. Pastor, J. Electroanal. Chem., 1995, 383, 181.

44 F. Kitamura, T. Ohsaka and K. Tokuda, Electrochim. Acta, 1997, 42, 1235.

45 M. Futamata, J. Electroanal. Chem., 2003, 93, 550-551.

46 Th. Wandlowski, K. Ataka, S. Pronkin and D. Diesing, Electrochim. Acta, 2004, 49, 1233.

47 J. Brooker, P. A. Christensen, A. Hamnett, R. He and C. A. Paliteiro, Faraday Discuss., 1992, 94, 339.

48 M. Watanabe and M. Motoo, J. Electroanal. Chem., 1975, 60, 267.

49 M. Śmiechowski and J. Stangret, J. Mol. Struct., 2007, 834-836, 239.

50 D. Schioberg and G. Zundel, J. Chem. Soc., Faraday Trans. 2, 1973, 69, 771 .

51 N. B. Librovich, V. P. Sakun and N. D. Sokolov, Chem. Phys., 1979, 39, 351.

52 CRC Handbook of Chemistry and Physics, ed. R. C. Weast, CRC Press, Florida, 66th edn, 1986.

$53 \mathrm{~W}$. Vielstich, Brennstoffelemente, Verlag Chemie $\mathrm{GmBH}$, Weinheim, 1965.

54 J. Crank, The Mathematics of Diffusion, Clarendon Press, Oxford, 2nd edn, 1975.

55 D. Britz, Digital Simulation in Electrochemistry, Springer, Berlin, 3rd edn, 2005. 